\title{
¿Es el Realismo Estructural Óntico una forma de pitagorismo?
}

\author{
Is Ontic Structural Realism a form of \\ Pythagoreanism?
}

Fernando Salcedo García Universidad Autónoma Metropolitana - Unidad Iztapalapa salcedogarcia91@gmail.com

\section{Resumen}

En este artículo pretendo argumentar a favor de la identificación que Otávio Bueno señala entre el Realismo Estructural Óntico y el pitagorismo, esto es, defender la idea de que ambas doctrinas afirman que el elemento básico o sustancia de la realidad es de naturaleza matemática.

Palabras clave: Realismo Estructural Óntico; pitagorismo; ontología; metafísica. 


\begin{abstract}
The purpose of this paper is to argue in favor of the identification between Ontic Structural Realism and Pythagoreanism, first observed by Otávio Bueno. So, the aim is to defend the idea that both theories assert that the basic element or substance of reality, have a mathematical nature.

Key words: Ontic Structural Realism; Pythagoreanism; ontology; metaphysics.
\end{abstract}

\title{
Introducción
}

El presente texto fue motivado por una problemática que el Realismo Estructural Óntico (REO) presenta, evidenciada por Otávio Bueno en su ensayo Structural Empiricism, Again (2011). En dicho texto, Bueno sugiere, en pocas líneas, que es lícito considerar que el REO es una «forma de» filosofía pitagórica, debido a que ambas posturas comparten compromisos metafísicos y ontológicos muy similares; en resumidas cuentas, ambas doctrinas afirman que el elemento básico o sustancia de la realidad es de naturaleza matemática.

Dicho esto, mi propósito es afirmar y ofrecer evidencia a favor de la identificación que Bueno señala entre el REO y el pitagorismo (P), para lo cual, en primer lugar, ofrezco una 
caracterización del REO en los términos que James Ladyman y Steven French emplean, y, en segundo lugar, recurro a autores como Aristóteles, Bueno y Goldin, entre otros. Así, espero que esta pequeña investigación sea adecuada para motivar la elaboración de futuros trabajos en donde, ahora, se pretenda desligar al REO del P de manera total.

\section{1. ¿Qué es el REO?}

Lo primero que hay que afirmar acerca el REO es que es una forma modificada y mejorada del realismo estructural (RE) desarrollado por Worrall. Así, creo más conveniente concentrarme primero en esta anterior forma de realismo. El surgimiento de dicho realismo estuvo motivado por la pugna existente entre dos posturas acerca del estatus de las teorías científicas, cada una de las cuales presenta su propio argumento. Por su parte, el realismo recurre al argumento de los no-milagros ${ }^{1}$, mientras que el antirrealismo presenta la metainducción pesimista como un poderoso ataque al primero. A continuación, expondré brevemente ambos argumentos.

El argumento de los no-milagros afirma que las mejores teorías científicas que aceptamos actualmente deben su capacidad para hacer predicciones novedosas no a un mero

${ }^{1}$ Worrall acuña este término en su ensayo de 1989, Structural Realism:

The Best of Both Worlds? 
milagro o a una «coincidencia de escalas cósmicas», sino a que logran describir adecuada y verdaderamente cómo es que el mundo funciona, más allá de los fenómenos. Esto lleva al realista a afirmar que aquello que las teorías describen ocurre realmente en el mundo, es decir, que son verdaderas o aproximadamente verdaderas:

It would be a miracle [...] if a theory made as many correct empirical predictions as, say, the general theory of relativity or the photon theory of light without what that theory says about the fundamental structure of the universe being correct or «essentially» o «basically» correct. But we shouldn't accept miracles [...] If what these theories say is going on «behind» the phenomena is indeed true or «approximately true» then it is no wonder that they get the phenomena right. So, it is plausible to conclude that presently accepted theories are indeed «essentially» correct (Worrall, 1989: 101).

La afirmación de carácter realista que el argumento de los nomilagros pretende defender es que las entidades postuladas en las teorías científicas tienen una existencia objetiva, es decir, que existen de forma independiente a cualquier mente. Así, por ejemplo, la teoría newtoniana de la gravitación universal afirma que la fuerza con la cual dos cuerpos de masas distintas se atraen depende del valor que dichas masas tengan y de la distancia (calculada al cuadrado) que exista entre dichos cuerpos. Ahora, según el argumento expuesto, 
el realista debería aceptar que entidades postuladas en la teoría, como la fuerza con la que los objetos se atraen, tienen una existencia real. $Y$ es en la medida en que se asuma que esto es así, que puede afirmarse que la teoría en cuestión es verdadera o aproximadamente verdadera. Por lo tanto, si se considera que una teoría es verdadera, también se considera que es debido a esto que puede llevar a cabo predicciones novedosas. Entonces, la postura realista, defendida por el argumento de los no-milagros, puede resumirse así: una teoría científica puede hacer predicciones novedosas si se considera que es verdadera, en virtud de que aquello que describe acerca del mundo es el caso.

Por parte del antirrealismo, la meta-inducción pesimista niega que podamos siquiera atribuir una verdad aproximada a nuestras teorías actuales, debido a un simple proceso inductivo. Considérese el siguiente argumento: en el caso 1 se observó que la teoría $\alpha$ resultó ser falsa; en el caso 2 se observó que la teoría $\beta$ resultó ser falsa; en el caso 3 se observó que la teoría $\gamma$ resultó ser falsa; $[. .$.$] en el caso N$ se observó que la teoría $n$ resultó ser falsa; por lo tanto no hay garantía ni evidencia a favor de que la teoría $n+1$ no sea falsa (es decir, que sea verdadera). Las premisas a las cuales la meta-inducción recurre son casos contenidos en la historia de la ciencia en donde ciertas teorías científicas, que en su momento fueron aplaudidas y aceptadas como ciertas, con el tiempo fueron reemplazadas por otras empírica o matemáticamente más adecuadas. Considérese, por ejemplo, 
el cambio del geocentrismo de Aristóteles y Ptolomeo, al heliocentrismo defendido por Copérnico y Galileo; es claro que actualmente no aceptaríamos la creencia de que la Tierra es el centro del universo, alrededor de la cual todos los demás astros, incluido el sol, giran. Este cambio o reemplazo de las teorías es conocido como «cambio teórico», y es fundamental tenerlo en mente si es que se pretenden comprender los motivos del REO. Por lo tanto, el fundamento de la metainducción pesimista es afirmar que

[t]his picture of theory-change in the past would seem to supply good inductive grounds for holding that those theories presently accepted in science will, within a reasonable brief period, themselves be replaced by theories which retain (and extend) the empirical success of present theories, but do so on the basis of underlying theoretical assumptions entirely at odds with those presently accepted (Worral, 1989: 109).

En resumen, el argumento de los no-milagros afirma que el que las teorías científicas aceptadas puedan hacer predicciones exitosas (tengan «éxito empírico», en la terminología de Worrall) depende del hecho de que logren describir adecuadamente al mundo, es decir, del hecho de que son verdaderas o aproximadamente verdaderas. Por su parte, la meta-inducción pesimista afirma que este optimismo en torno a la certeza de las teorías científicas está 
mal fundado, pues existe evidencia (pero ¿será la suficiente?), a favor de que las teorías científicas pueden resultar ser, en determinado momento, falsas.

Algo que considero sumamente importante destacar es que ambos argumentos dependen de lo que llamo la «dimensión ontológica» de las teorías científicas. Por esta dimensión entiendo al mismo contenido de carácter pretendidamente descriptivo de las teorías, el cual procura dar cuenta de la naturaleza u ontología de las entidades postuladas. Por ejemplo, recurriendo de nuevo a la teoría de la gravitación universal, su dimensión ontológica estaría compuesta por la afirmación de que «la fuerza ejercida entre dos cuerpos de masas $m 1$ y $m 2$, separados por una distancia $\mathrm{r}$, es proporcional al producto de $m 1$ y $m 2$ e inversamente proporcional al cuadrado de $r »$, lo cual implica una forma de definir la naturaleza misma de la fuerza gravitatoria de los cuerpos ('la fuerza de atracción entre los cuerpos es tal y tal'). Así, la dimensión ontológica de las teorías está compuesta por el contenido de la teoría (expresado en su misma enunciación), por lo cual es lícito afirmar una identidad entre ambos. Así, el realismo, recurriendo al argumento de los nomilagros, se fundamenta en el hecho de considerar que la dimensión ontológica de una teoría es una descripción fiel o verdadera de lo que sucede en la realidad, mientras que el antirrealismo, invocando a la meta-inducción pesimista, afirma que el cambio teórico se da en el momento en que las dimensiones ontológicas de dos teorías rivales entran en 
conflicto. $\mathrm{Y}$ es precisamente aquí donde entra en escena el RE.

Como se dijo al inicio de esta sección, el RE surge a partir de los dos argumentos en oposición que tanto el realismo como el antirrealismo presentan, como un intento de conciliar ambas posturas y de recuperar lo mejor de ambas. En esencia, lo que el RE debe de poder llevar a cabo son dos cosas: (1) dar cuentan del éxito empírico de las teorías (su capacidad para hacer predicciones novedosas), y (2) no ser víctima de la meta-inducción pesimista ${ }^{2}$. Para poder hacer frente a estas dos cuestiones, el RE recurre al concepto de continuidad de estructura en las teorías científicas, como su pilar fundamental. Tomando como ejemplo la continuidad entre las teorías de Fresnel y Maxwell ${ }^{3}$ respecto a la constitución (o naturaleza) de la luz, Worrall afirma que:

There was an important element of continuity in the shift from Fresnel to Maxwell - and this was much more than a simple question of carrying over the successful empirical content ${ }^{4}$ into the new theory. [...] And what was carried over can be captured without

2 De hecho, puede entenderse al RE como una versión mejorada del realismo científico tradicional, a partir del cual se ha de evitar caer en el argumento de la meta-inducción pesimista.

${ }^{3}$ Ver Worrall (1989).

${ }^{4}$ Este mencionado «contenido empírico» de las teorías no es más que su dimensión ontológica. 
making the very far-fetched assumption of Harding and Rosenberg that Fresnel's theory was «really» about the electromagnetic field all along. There was a continuity or accumulation in the shift, but the continuity is one of form or structure, not of content (Worral, 1989: 117).

De esta manera, "[t]his example of an important theorychange in science certainly appears, then, to exhibit cumulative growth at the structural level combined with radical replacement of the previous ontological ideas. It speaks, then, in favour of a structural realism ${ }^{5}$ (Worral, 1989: 120). La naturaleza de las estructuras que subyacen a los conceptos teóricos no es suficiente o claramente desarrollada por Worrall, pero lo que se ha de entender al respecto es que son de naturaleza matemática.

Considérense las siguientes afirmaciones hechas por Worrall: «Thus if we restrict ourselves to the level of mathematical equations - not notice the phenomenal levelthere is in fact complete continuity between Fresnel's and Maxwell's theories» (Worral, 1989: 119, cursivas mías). «On the structural realist view what Newton really discovered are the relationships between phenomena expressed in the

5 «According to Worrall, we should not accept full-blown scientific realism, which asserts that the nature of things is correctly described by the metaphysical and physical content of our best theories. Rather we should adopt the structural realist emphasis on the mathematical or structural content of our theories» (Ladyman, 1997: 409). 
mathematical equations of his theory» (Worral, 1989: 122, cursivas mías). Por lo tanto, las estructuras que persisten a lo largo del cambio teórico deben concebirse como «entidades matemáticas» ${ }^{6}$. Así, la dimensión formal corresponde al contenido matemático de las teorías, mientras que la ontológica a su contenido «físico y metafísico».

Ahora, respecto a las dos cosas que el RE debe de poder llevar a cabo:

(1) El hecho de que las teorías tengan éxito empírico se debe a que éstas logran «capturar» la estructura correcta del mundo o, mejor, la estructura de cierto aspecto o entidad del mundo, como la fuerza gravitacional o la luz. Recurriendo al ejemplo anterior, el que la teoría de la gravitación universal sea empíricamente exitosa (a tal grado que actualmente se la sigue considerando como verdadera) se debe a que logra capturar adecuadamente la estructura de la fuerza gravitacional. Así, el RE puede dar cuenta de la capacidad de las teorías para hacer predicciones novedosas recurriendo a la noción de estructura, apegándose, así, al argumento de los no-milagros.

(2) En segundo lugar, el RE evita caer en la meta-inducción pesimista al afirmar que el cambio teórico se da únicamente en la dimensión ontológica de las teorías, y

${ }^{6}$ En el caso de la teoría de la gravitación universal, su estructura matemática estaría expresada por la ecuación: $F=G \frac{m_{1} m_{2}}{r^{2}}$. 
no a nivel estructural. Precisamente a esto se refiere Worrall al afirmar que «la continuidad es de forma o estructura, no de contenido», la cual se manifiesta a lo largo de las revoluciones científicas.

Tal y como Worrall lo formula, parece ser que el RE es de naturaleza meramente epistémica. Si esto es así, entonces puede afirmarse que podemos tener conocimiento de la estructura matemática de las entidades teóricas (es decir, que el conocimiento de las estructuras funge como un constreñimiento en nuestro conocimiento del mundo), pero que no podemos tener acceso a su verdadera naturaleza. Si bien esta caracterización del RE como teniendo una naturaleza epistémica no es algo que Worrall afirme explícitamente, sí es algo que, me parece, sugiere en ciertos pasajes: «Roughly speaking, it seems right to say that Fresnel completely misidentified the nature of light» (Worral, 1989: 117 , cursivas mías); «[T]he structural realist [...] insists that it is a mistake to think that we can ever "understand" the nature of the basic furniture of the universe» (Worral, 1989: 122, cursivas mías). Así, me parece sensato afirmar que Worrall, pese a su énfasis en la estructura de las entidades teóricas, igualmente considera que existe una «realidad fundamental» o «básica» del universo, la cual no se agota en las estructuras matemáticas. Dicho esto, puede considerarse al RE expuesto por Worrall como un realismo estructural epistémico (REE), definido por Psillos de la siguiente manera: 
[Structural realism] has two options available. Either there is something other than structure - call it X- in the world, which however cannot be known, or there is nothing else in the world to be known. On the first disjunct, the restriction imposed by [structural realism] is epistemic. Call this view Restrictive Structural Realism (RSR). (Psillos, 2001: S18).

Parece justo, entonces, considerar al REE de Worrall como el equivalente del RSR de Psillos. El punto es afirmar que existe algo que trasciende las estructuras, pero que no podemos conocer, y me parece que Worrall tácitamente adopta al REE. No obstante, a esta versión epistémica del RE se le presentan serias dificultades (que no expondré en el presente), que son exhibidas por Ladyman7, quien, una vez considerado esto, opta por una versión metafísica u óntica del RE: el REO. Por cuestiones de pertinencia y oportunidad no ahondaré demasiado en los detalles de esta versión del realismo de Ladyman, y haré énfasis únicamente en los compromisos metafísicos que adquiere respecto a las estructuras, las cuales, como se vio en Worrall, mantendrán su naturaleza matemática.

El REO sostiene, esencialmente, dos compromisos metafísicos: (1) el mundo y las cosas tienen una estructura

7 Ver Ladyman (1997). 
objetiva, y (2) tal estructura es ontológicamente fundamental o primitiva:

Ontic Structural Realism (OSR) is the view that the world has an objective modal structure that is ontologically fundamental, in the sense of not supervening on the intrinsic properties of a set of individuals. [...] Hence, a first aproximation to our metaphysics is: 'There are no things. Structure is all there is' (Ladyman \& Ross, 2007: 130).

Esto quiere decir que, a diferencia del REE, el REO no considera que exista ese algo además de las estructuras matemáticas (el «X» mencionado por Psillos), sino que afirma que lo único que existe son tales estructuras, las cuales constituyen la «realidad última» del mundo: «El mundo es estructura» sería un buen eslogan para esta versión del RE. Esto, por supuesto, no quiere decir que el REO esté negando que los objetos, el mundo mismo, tengan una constitución ontológica o una «naturaleza»; lo que este realismo intenta es cambiar o reemplazar la forma en que se conceptualiza dicha naturaleza:

[W] e regard the ontic form of [structural realism] as offering a reconceptualisation of ontology, at the most basic metaphysical level, which effects a shift from objects to structures. [...] Let us be clear: we are not 'anti-ontology' in the sense of urging a move away 
from electrons, elementary particles etc. and towards 'observable structures' or the S-matrix or whatever; rather, we urge the reconceptualization of electrons, elementary particles and so forth in structural instead of individualistic terms (French \& Ladyman, 2003: 37).

Así, el REO pretende dar un salto desde una ontología de objetos y relaciones entre ellos, a una ontología de estructuras, es decir, hablar de las cosas contenidas en el mundo (y del mundo mismo) en términos puramente estructurales, pues son lo único que hay, y nada más.

Ahora, haciendo a un lado ciertos problemas de subdeterminación metafísica que se presentan en el terreno de la física cuántica, los cuales (en parte junto con las fallas que el REE presenta) promovieron el desarrollo del REO por parte de Ladyman y French ${ }^{8}$, me parece importante destacar lo siguiente: la noción de estructura que el REO utiliza es heredada del $\mathrm{REE}^{9}$, particularmente de la versión que Worrall presenta. Como podrá recordarse, Worrall afirma que la dimensión de las teorías que subsiste a lo largo del cambio teórico, capaz de explicar su éxito empírico, es la estructural o formal, considerándola como una entidad

8 Ver French \& Ladyman (2003).

${ }^{9}$ Hay que señalar que el que el REO haya heredado la concepción de las estructuras del REE no significa que las representa de la misma manera; el REE se atine a la representación de las estructuras a partir de las oraciones Ramsey, mientras que el REO, particularmente el de Ladyman, utiliza los llamados modelos teóricos. 
matemática abstracta ${ }^{10}$. $\mathrm{Al}$ respecto, French y Ladyman afirman que «[m]athematical equations represent one component of theoretical structure but non-mathematical, qualitative aspects can also be represented through resources of logic and set theory» (French \& Ladyman, 2003: 32). Creo que esto favorece la idea de que, para el REO, cualquier aspecto del mundo, sea cualitativo o cuantitativo, puede representarse apelando a entidades matemáticas, particularmente a las postuladas por la teoría de conjuntos:

One way of explicating the relevant structure in mathematical terms is through group theory and Castellani, for example, has begun to explore the ontological representation of the fundamental objects of physics in terms of sets of group-theoretic invariants by Weyl, Wigner, Piron, Jauch and others (French \& Ladyman, 2003: 37).

En resumen, para el REO todo lo que hay en el mundo, esencialmente, son estructuras que tienen una existencia primitiva y objetiva, y que son de naturaleza matemática.

${ }^{10}$ Es decir, que si bien carece de propiedades espacio-temporales, se le considera como subsistente. 


\section{2. ¿Es el Realismo Estructural Óntico una forma de pitagorismo?}

Las tesis fundamentales del REO que han de mantenerse, si es que se quiere responder a la pregunta anterior, son tres; las dos primeras contienen a los compromisos metafísicos, anteriormente descritos, que este tipo de realismo adquiere en su caracterización alternativa al REE: (1) el mundo y las cosas tienen una estructura objetiva, y (2) tal estructura es ontológicamente fundamental o primitiva. Por último, (3) la «naturaleza» de tal estructura es matemática. De manera general, entonces, el realista estructural óntico ha de conceder la verdad de dos afirmaciones si es que, en primer lugar, pretende seguir afirmándose como realista, en segundo lugar, como realista estructural y, en tercer lugar, como realista estructural óntico: (a) las estructuras son entidades matemáticas cuya existencia es objetiva y (b) tales entidades forman a la sustancia primigenia de la realidad. Ahora, ¿qué tiene que ver todo esto con el pitagorismo? Si se le preguntara a Aristóteles, diría que mucho; el estagirita sin duda afirmaría que el REO es una especie de neopitagorismo, considerando a sus miembros como seguidores particularmente de las doctrinas ontológicas de Filolao $^{11}$.

${ }^{11}$ En la medida en que fue el primer pitagórico en dejar sus ideas por escrito, a sus textos se les consideran la principal fuente de las doctrinas pitagóricas. Igualmente, el pitagorismo no debe reducirse a sus doctrinas ontológicas en torno a la noción de número; éste figuraba solamente 
Pero ¿por qué afirmaría esto? Para responder a esto, hay que tener en mente las tres tesis fundamentales del REO mencionadas al inicio de esta sección. Ahora, considérese la siguiente cita de la Metafísica:

[T]he so-called Pythagoreans, in their interest in mathematics, were the first to bring these in and, being involved in them, they thought that the principles of mathematical entities were the principles of all entities. And since of mathematical entities numbers are by nature primary, and among these they seemed to observe many similarities with entities and things coming into being, rather than in fire and earth and water, so that such and such an affection of numbers is justice and such and such soul and mind and another time and with each of the things likewise [...] Since then all other things seemed to be assimilable to numbers in their nature, and the numbers were primary of the whole of nature, they assumed that the elements of the numbers were the elements of things as a whole, and they thought that the whole heaven was a harmony and a number (Aristóteles, 1998: 19 20).

como uno entre diversos temas que los pitagóricos desarrollaron, entre los que se encuentran cuestiones concernientes a la vida moral, política y a la filosofía natural. 
Es evidente el parecido entre la caracterización que hace Aristóteles del P, y la caracterización que ofrecen tanto Ladyman como French del REO. En primer lugar, ambas posiciones filosóficas consideran a entidades matemáticas como el principio o sustancia ( $\dot{\alpha} \varrho \chi \alpha i$ í) de todas las cosas; los pitagóricos afirmaban al número como dicha sustancia, mientras que el REO propone a las ecuaciones matemáticas y a los conjuntos (como entidades propuestas por la teoría de conjuntos). Y es que los pitagóricos realmente pensaban que todo lo existente está hecho literalmente de números:

Like the Milesians Anaximander and Anaximenes as well as other 'Presocratics', [Pythagoras], too, seems to have been driven by an indomitable desire to know (íTo@í $\alpha$ ), and in particular to discover the primordial

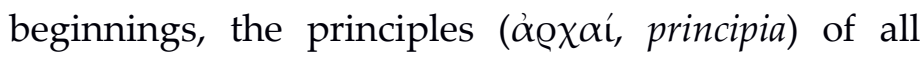
things. But instead of air, 'water and earth', fire or the

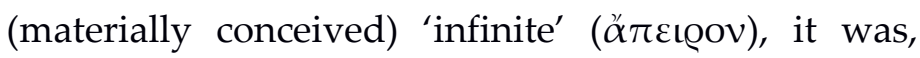
interestingly enough, 'number' that in the school of Pythagoras was proposed as 'principle' or as the (still materially understood) primary substance: from number originated everything in this world (even heaven itself), and out of number it will continue to exist - that's how the basic assumption runs, an assumption that hasn't lost any of its fascination even today (Riedweg, 2012: 52-53).

Por su parte, para el REO las estructuras matemáticas son ontológicamente fundamentales, lo cual significa que no puede 
existir algo que las trascienda, en un sentido ontológico estricto (como podrá recordarse, el afirmar esto es lo que, en parte, supone la gran diferencia existente entre el REO y el REE). Por lo tanto, este primer punto de encuentro se resume en lo siguiente: el principio ontológicamente fundamental de toda entidad es, para $\mathrm{P}$, el número $\mathrm{y}$, para el REO, las estructuras, es decir, en ambos casos entidades matemáticas.

$\mathrm{Y}$, en segundo lugar, ambas doctrinas mantienen que las entidades matemáticas (en el presente caso, 'número' y 'estructuras') tienen una existencia objetiva, es decir, independiente de nuestras propias mentes. Para el $\mathrm{P}$ esto es así, debido a que se considera que el componente primitivo de las cosas del mundo, siendo éstas objetivamente existentes, debe de tener una existencia igualmente objetiva, de tal forma que «[a]ccording to the Pythagoreans, sensible things exist by imitating ( $\mu$ í $\mu \eta \sigma \varsigma)$ numbers» (Zhmud, 2012: 334). Es claro, por lo tanto, que tanto el $\mathrm{P}$ como el REO mantienen una posición realista acerca de sus respectivas entidades matemáticas. Por lo tanto, parece ser que el $\mathrm{P}$ igualmente participa de los compromisos metafísicos y ontológicos respecto a la «realidad última» del mundo, los cuales son explícitamente formulados por Ladyman, así que podríamos estar de acuerdo con Bueno cuando afirma que

[i]n the set-theoretic account of structure, the latter is, of course, an abstract construction (it is part of the settheoretic hierarchy). Thus, it seems that if the structural realist countenances this notion of structure, he or she 
will have to be a mathematical realist as well. Now, in the ontological formulation of structural realism provided by Ladyman, this seems to entail that the structural realist is committed to some sort of Pythagoreanism. [...] But then [...] the world itself seems to become a mathematical entity (an alternative that, I take it, few would be happy with) (Bueno, 2011: $83)$.

Llegado este punto, me parece que podría, al menos, comenzar a figurarse una posible objeción a la discutida identificación entre ambas posturas. La cuestión radica, específicamente, en las entidades en torno a las cuales el $\mathrm{P}$ y el REO mantienen una postura realista. Las entidades matemáticas que $\mathrm{P}$ afirma como ontológicamente fundamentales son los 'números', mientras que el REO afirma a las 'estructuras'. Si bien ambos conceptos denotan entidades de naturaleza matemática, esto no parece implicar que el REO, estrictamente, sea una forma de P. Dicho de otra forma, podría afirmarse que una doctrina califica como pitagórica si y sólo si afirma que son los números, y no otra cosa, las entidades matemáticas ontológicamente fundamentales. Si el anterior bicondicional es verdadero, entonces es incorrecto afirmar al REO como formando parte del P. No obstante, parece ser que concluir lo anterior es incorrecto, pues, como Goldin afirma, 
[y]es, the Pythagoreans restrict their ontology to numbers, while contemporary structural realists are open to structures of all kinds. But numbers, taken either individually or in relation to one another, are examples of structure. Not all structures can be expressed numerically, and for the Pythagoreans as for all ancient Greeks, numbers would be integers, for which reason continuous structures would not be accepted in Pythagorean ontology. But if one accepts the thesis of pancomputationalism ${ }^{12}$, the correspondence would be more exact, as all Turing machines manipulate discrete data, and all discrete data can be encoded as a series of binary elements, $0 \mathrm{~s}$ and 1s, which together can be understood as constituting numbers (Goldin, 2016: 14).

El punto es, entonces, que si se afirma que los números son ellos mismos estructuras, entonces se debe afirmar, también, que el hecho de mantener una posición realista respecto a números es mantener una posición realista respecto a estructuras. En este caso, parece ser que, en sentido opuesto al que se ha venido discutiendo, se debe afirmar que es el $\mathrm{P}$ quien realmente es una forma de REO. No obstante, esta conclusión pierde fuerza si se consideran las siguientes dos

12 «[P]ancomputationalists such as Edward Fredkin approach the Pythagorean account insofar as on their account all reality can in principle be expressed as one (very big) number, made up of discrete units» (Goldin, 2016: 3). 
cuestiones: (1) el fundamento de la identificación entre el P y el REO radica en que lo que es ontológicamente fundamental para ambas posturas son entidades matemáticas, es decir, que tanto los números como las estructuras tienen el mismo estatus ontológico (y esto es algo que tanto Bueno como Goldin dan por cierto). Además, (2) si se afirma que los números son estructuras, entonces ser realista sobre estructuras implica ser realista sobre números; incluso si se mantiene la afirmación de que no todas las estructuras pueden ser «expresadas numéricamente» (ver cita anterior), es decir, que no todas las estructuras son números, es claro que, por lo menos algunas sí pueden serlo. Entonces, podría seguirse manteniendo que, al menos en cierto grado, «contemporary structural realists posit an ontology much like that of Aristotle's "Pythagoreans"» (Goldin, 2016: 3) ${ }^{13}$.

A partir de todo esto, es evidente que el problema con el REO radica en sus compromisos metafísicos y ontológicos. No obstante, si éste decidiera abandonarlos, entonces podría objetársele que dejaría de defender precisamente aquellas tesis que lo caracterizan:

${ }^{13}$ Nótese que, al respecto, Bueno afirma que el REO es una forma de («sort of») pitagorismo, y que Goldin, por su parte, afirma que la ontología propuesta por el REO es parecida («much like») a la propuesta por P. Es claro, entonces, que ambos autores no afirman una similitud total y exacta entre el $\mathrm{P}$ y el REO, sino que únicamente son parecidas (en un grado considerable). 
The problem arises because of the metaphysical nature of the structures that are required by the [ontic] structural realist; that is, such structures need to exist, be independent of us, and constitute the ultimate features of reality. If we drop these metaphysical requirements, the difficulty vanishes. For in this case, we need not assume that there are mathematical structures in the first place. However, without demanding a metaphysical account of structure, it's unclear that [ontic] structural realism is still a version of realism. After all, if structures have no metaphysical significance, there is nothing there for the structural realist to be realist about (Bueno, 2011: 83).

Para replicar su caracterización como P, el REO tiene, a como lo veo, dos posibilidades: la primera es negar el estatus ontológico de las estructuras. No obstante, como Bueno afirma, esto lo llevaría a alejarse del realismo, lo cual, si bien no necesariamente lo convertiría en una forma de antirrealismo, sí en algo muy distinto a lo que inicialmente fue. La segunda alternativa es desarrollar a mayor profundidad la posible objeción que comencé a formular más arriba, es decir, aquella que dicta que una doctrina califica como pitagórica si y sólo si afirma que son los números, y no otra cosa, las entidades matemáticas ontológicamente fundamentales.

Para finalizar, creo importante únicamente mencionar que el problema de asumir al REO como $\mathrm{P}$ no radica 
simplemente en afirmar que, como Bueno, sería una «alternativa con la cual muy pocos estarían felices», sino que surge la cuestión en torno al cómo es que a partir de entidades matemáticas (números o estructuras) se puede constituir cualquier otra entidad que forma parte de la realidad, la cual es una crítica Aristóteles mismo formula:

But how can properties, white, sweet, hot and the rest, be numbers? In any case, it is surely clear that it is not numbers that are a thing's substance and responsible for its shape. [...] Do you mean that number is the matter of flesh and bone? It is in that the substance of these is three parts fire and two parts earth. Anyway, in all cases, a number, whatever it may be, is always a number of some things, whether of fire, of earth or of units. But the substance of a thing just is there being a certain amount to a certain amount in its mixture. And this is not just a number. It is a ratio of the mixture of numbers, be they numbers of body or of anything else (Aristóteles, 1998: 449).

Sin embargo, esta es una objeción que es material para otro trabajo. 


\section{Bibliografía}

Aristóteles (1998). Metaphysics. England: Penguin Books

Bueno, O. (2011). Structural Empiricism, Again. Bokulich, Alisa \& Bokulich, Peter (eds.). Scientific Structuralism. Boston: Springer.

French, S., y Ladyman, J. (2003). Remodeling Structural Realism: Quantum Physics and the Metaphysics of Structure. Synthese 136, 31-56.

French, S., y Ladyman, J. (2011). In Defense of Ontic Structural Realism. Bokulich, Alisa \& Bokulich, Peter (eds.). Scientific Structuralism. Boston: Springer.

Goldin, O. (2016). Aristotle, The Phytagoreans, and Structural Realism. The Review of Metaphysics Vol. 69 (No. 4), 687-707.

Ladyman, J. (1998). What is Structural Realism? Studies in History of Philosophy of Science Vol. 29 (No. 3), 409-424.

Ladyman, J., Ross, D., Spurret, D., y Collier, J. (2007).

Everything Must Go. New York: Oxford University Press.

McKirahan, R. (2013). Philolaus on Number, Cornelli, G.,

McKirahan, R., y Macris, C. (eds.). On Pythagoreanism.

Germany: de Gruyter.

Psillos, S. (2001). Is Structural Realism Possible? Philosophy of Science 68, S13-S24.

Riedweg, C. (2013). Approaching Pythagoras of Samos: Ritual, Natural Philosophy and Politics. Cornelli, G., 
McKirahan, R., y Macris, C. (eds.). On Pythagoreanism. Germany: de Gruyter.

Worral, J. (1989). Structural Realism: The Best of Both Worlds? Dialéctica Vol. 43 (No. 1-2), 99-124.

Zhmud, L. (2013). Phytagorean Number Doctrine in the Academy. Cornelli, G., McKirahan, R., y Macris, C. (eds.). On Pythagoreanism. Germany: de Gruyter. 